Final article:

Lindgreen, A. and Hingley, M.K. (2003), "The impact of food safety and animal welfare policies on supply chain management: the case of the Tesco meat supply chain", British Food Journal, Vol. 105, No. 6, pp. 328-349. (ISSN 0007-070X)

For full article, please contact LindgreenA@ cardiff.ac.uk

\title{
The Impact of Food Safety and Animal Welfare Policies on Supply Chain Management: The Case of the Tesco Meat Supply Chain
}

\author{
Adam Lindgreen, $\mathbf{P h D}^{1,2}$ \\ Technical University of Eindhoven \\ Eindhoven, the Netherlands \\ and \\ Martin Hingley ${ }^{3}$ \\ Harper Adams University College \\ Newport, Shropshire, United Kingdom
}

\footnotetext{
${ }^{1}$ Senior lecturer, Dr. Adam Lindgreen, Avenue du Centre Sportif 45 Bte 8, Wavre 1300, Belgium. Telephone $+32-$ (0) 1022 2743. Fax + 32 - (0) 25209690 (Attention: Lindgreen). E-mail Adam_Lindgreen@ hotmail.com. The author is a senior lecturer with the Technical University of Eindhoven in the Netherlands, a visiting professor with Auckland University of Technology in New Zealand, and a visiting reader with Harper Adams University College in the UK.

${ }^{2}$ Part of this article was written when the author was a Visiting Professor with Auckland University of Technology. The author wishes to thank the university for inviting him, which allowed him to continue his research. The author also gives thanks to the Danish Research Academy, the National Fund for Scientific Research in Belgium, and the Catholic University of Louvain in Belgium for generous financial support. Both authors contributed equally. They wish to thank Tesco and the supplier firms that participated in this research.

${ }^{3}$ Senior lecturer Martin Hingley, School of Management, Harper Adams University College, Newport, Shropshire, TF10 8NB, United Kingdom. Telephone + 44 - (0) 1952815 386. Fax + 44 - (0) 1952814783 . E-mail mhingley@ harper-adams.ac.uk. The author is also the Tesco Teaching Fellow at Harper Adams University College.
} 


\section{Word count: 8,631 (excluding tables, figures, appendices, and references) Abstract}

The European food sector has been hit by a number of serious consumer scares over the past decades. Often, the concerned companies have failed to give appropriate and immediate information to consumers. This article discusses the measures that one food company - Tesco has taken. Their approach deals with setting up effective guidelines for managing their relationships with meat suppliers. These guidelines make it possible for Tesco to inform consumers appropriately and immediately about serious food scares and to address consumers' concerns over animal welfare and environmental issues. The article also describes how the meat supplier - Tesco relationships are being evaluated using the so-called key performance indicator process. Specific initiatives include different animal, feeds, and medicines policies, as well as meat assurance schemes; these policies and schemes have been implemented by both Tesco and the meat suppliers. The benefits of Tesco's approach to its suppliers and consumers are considered and include the ability to deliver higher value products. The article suggests a number of avenues for future research.

Keywords: Animal welfare; Food scares; Key performance indicator evaluation; Relationships; Supply chain management; Tesco

\section{Introduction}


We consider the approach that Tesco has taken in dealing with consumers' concern about food scares and animal welfare. This approach is challenging the traditional and complex UK meat supply chain, since Tesco buys directly from suppliers and uses a centralised distribution system. This means that the supply chain is now being viewed as one supply chain and not as a number of more independent supply chains. Additionally, Tesco's approach includes setting up effective guidelines for managing their relationships with meat suppliers.

\section{Structure of Article}

Our article is based upon a single case study and is the first in a series of studies that examine the strategies that food companies have adopted in order to deal with consumer's concerns. We chose to conduct a first case study to get an initial idea of the opportunities and threats that food companies are faced with when they are communicating to various influence markets and how they are responding to consumers' concerns about food scares and animal welfare.

We first give a brief overview of some of the food scares that have hit the European food sector over the past decades. Then we examine how those concerned in the food supply chain often have failed to give appropriate and immediate information to consumers.

Moving on, we describe the research methodology, which was a single case study on Tesco, the single largest food retailer in the UK. Evidence was collected using a number of sources including in-depth interviews with both Tesco and four of its meat suppliers (covering most of the major meat products), as well as secondary data. We then report on the case findings. The initiatives, which Tesco has implemented, include carrying out in-depth research on how to keep 
and transport livestock; this is done together with research institutions, and the results of the research are being shared with farmers, suppliers, and consumers. Another initiative has been the establishing of food safety and animal welfare policies that suppliers are required to comply with. The meat suppliers have also implemented a number of initiatives, for example the 'Best Beef Scheme', which aims to provide a completely traceable, welfare-driven beef chain, and the 'Producer's Club' concept. We also describe how the meat supplier - Tesco relationships are being evaluated using the so-called key performance indicator process, as well as discuss what meat suppliers think of being evaluated. It has been necessary to change how Tesco is communicating with its meat suppliers, and this is examined. The benefits of relationship forming are discussed and include being able to deliver products of better value to the consumers. Throughout this part of the presentation, we cite explicit presentations of the key evidence, which were used to draw conclusions. This is done by presenting selected text evidence that is representative and supportive of our research findings.

We finish the article by outlining managerial implications of the research including, for example, how meat suppliers now have to co-operate with competitors when they become part of the same category team. We also discuss limitations of our research, as well as possible future research. One future avenue is to look at trust-building activities during a food crisis. Another avenue is to examine the advantages and disadvantages of having a small supplier base. Yet a third avenue would be to consider how, if at all, it is possible to have competitors working together even though they are competing for the same retailer.

\section{Literature Review}


Over the past decades, the food sector in Europe has being faced a number of serious consumer scares (e.g., Jolly, Schultz, Diaz-Knauf, and Johal 1989; Sharp and Reilly 1994; Wandel 1994; Zimmerman, Kendall, Stone, and Hoban 1994). One case in point was in March 1996 when the British government admitted that mad cow disease, or bovine spongiform encephalophathies (BSE), most likely had killed ten people (e.g., The Economist 1998a, 1998b). The British government paid some $£ 1,500$ million pounds for cattle to be destroyed in 1997 making mad cow disease, at the time, the single most expensive catastrophe to have befallen British agriculture. Another case has been the many incidents of bacterially contaminated meat of Camphylobacter, Escherichia coli, Listeria monocytogenes, and Salmonella (e.g., Licking and Carey 1999; Schaffner, Schroder, and Earle 1998; Sharp and Reilly 1994; Tansey and Worsley 1995).

Although not directly threatening to humans, the most recent food scare was the incidence of foot-and-mouth disease in Britain. This, the most serious outbreak since 1967, was notified in February 2001. Only by August 2001 was the outbreak contained, but not fully eradicated, with almost 2,000 confirmed cases, resulting in the slaughter of over 3.5 million animals. The cost to the taxpayer for the clean up of the disease has been high and put at $£ 2,200$ million (Daily Telegraph 2001). By the end of 2001, the outbreak was over. The UK Ministry Department for Environment Food and Rural Affairs recorded 9,323 premises on which animals had been slaughtered or where earmarked for slaughter, and a final slaughter total of just under 4 million animals (Department for Environment Food and Rural Affairs 2001). Although, as stated, footand-mouth disease is not directly hazardous to human health, the seriousness of the outbreak was intensively covered in the national media over many weeks and has raised consumers' concern of livestock farming and food-related issues. An extensive consumer attitudinal study conducted by the Gallup Organisation during the 2001 foot-and-mouth crisis in the UK found a heightened 
consumer awareness, with evidence of greater importance being attributed to issues such as farm animal welfare and rearing methods of farm animals. Further, findings identified a declaration from some consumers that they would be prepared to pay more for assurances of higher welfare standards (Freedom Food Survey 2001).

In many cases where there are understandable consumer concerns, food supply chain organisations have not always responded quickly enough in giving appropriate and immediate information to consumers (Goddard 1999). Systematic research on what companies could have done in a time of such a food scare would, therefore, be of interest for managers. In this article, the approach that one food company - Tesco - has taken is being examined. Their strategy deals with setting up effective guidelines for managing relationships with suppliers. These guidelines made it possible for Tesco to inform the public about food scares in general. The guidelines have been a major reason for the retailer's success in selling British meat and establishing equivalent standards to meat produced overseas on their behalf and imported into the UK.

Food industry supply is facing a process of concentration in all parts of the supply chain determined by backward vertical integration at the initiation of powerful multiple retail buyers (e.g., Hingley 2000; Hughes 1994; Tansey and Worsley 1995). This is notably prevalent in the UK where channel development in recent years has focused on close 'partnerships' between multiple retailer buyers and a reduced supply base of more significant suppliers to their businesses in given food categories (Hingley 2002). The Tesco relationship-based approach with regard to the management of their supply base comes at a time when UK supermarkets have come in for a considerable amount of criticism with regard to 'fair' dealings with suppliers. The Competition Commission report into competitiveness and supply chain management by UK 
retailers (Competition Commission 2000) highlights shortcomings in the treatment of suppliers to supermarkets. As a result, a code a practice has been drawn up by the Director General of Fair Trading in the UK to which Tesco and the other leading UK food retailers have agreed to comply with (Farmers Weekly Interactive 2001). The code governs relations between major supermarkets and their suppliers and puts in place measures to remedy problems identified by the Competition Commission relating to provision of independent dispute resolution and seeks to provide suppliers with greater certainty and security (Department of Trade and Industry 2001). However, the code has not been welcomed in all quarters, with notable criticism from UK farmers' leaders. Against this background of apparent unrest over supplier-retailer relationships it would be interesting to identify experiences from those engaged in close-partnering relationships and to comprehend the experiences of Tesco and their suppliers to one specific market, namely the livestock and meat sector.

\section{Research Issues}

The article will address the following issues:

- What, if at all, are the guidelines for the relationship between Tesco and their meat suppliers?

- What steps, if any, have Tesco and its meat suppliers taken to establish / re-establish consumer confidence in the meat and livestock sector?

- What role, if any, has partnership status/arrangements in the sector played in the establishment / re-establishment of consumer confidence in the meat and livestock sector? 


\section{Research Methodology}

A case study was carried out on Tesco. With 680 stores in the UK (907 stores world-wide) and 240,000 employees, Tesco's share of the UK food retail sales is 15.6 per cent, which makes Tesco the largest food retailer in the UK by 6 per cent of market share more than the nearest rival, J. Sainsbury, and Europe's second largest supermarket after French retailer Carrefour (Corporate Watch 2001). It also has overseas operations in France, Ireland, Eastern Europe (Czech Republic, Hungary, Poland, and Slovak Republic), and Southeast Asia (Malaysia, South Korea, Taiwan, and Thailand). The latest Tesco $1 / 2$ year turnover was $£ 11.5$ billion, up 14.2 per cent from last year, with projections for a group turnover in 2001/2 of over $£ 22$ billion (Tesco 2001). Not surprisingly, Tesco's requirements for meat products are significant: 6,000 cattle, 80,000 pigs, 20,000 lambs, and 1,200,000 chickens on a weekly basis (Ling 2001).

To correlate data from Tesco, the case study sought to investigate relationships at a dyadic level, which meant that both Tesco and, where possible, their meat suppliers were interviewed (Table 1). The research included interviews with organisations and personnel in current buyer-seller partnerships:

- Senior head office managers in buying and technical roles represented Tesco management. These managers have a regular interface with the selected supplier personnel.

- Supplier organisations were selected from the Tesco so-called 'partner supplier base'. Respondents were senior managers who have a good overview of the supply chain 
relationship with Tesco and of broader issues, too, rather than functional or line managers. Supplier organisations represented the principal dyadic interface with Tesco in the main product groups (i.e., the red and white meat sectors). The organisations, which were drawn from the main supply chain interface with Tesco, perform the functions of slaughtering, processing, and value adding, rather than livestock farming.

[Take in Table 1 about here]

An interview protocol was developed for research purposes (Appendix 1). The questions were semi-structured and were common to both Tesco personnel (A, in the protocol) and supplier personnel (B, in the protocol). The questions helped to elicit responses with regard to 'relationship factors' explored in the existing literature on business-to-business and supply chain relationships (e.g., Anderson and Narus 1990; Fontenot and Wilson 1997; Lindgreen 2001a; Wilson and Vlosky 1997). In total, six in-depth interviews were conducted. On average each interview lasted one hour. Market intelligence, which had already been published in trade journals, the business and financial press, and research publications, was also consulted. At Tesco, archival data was requested - this included business reports and guidelines for managing a business partnership, as well as annual reports, newsletters, and websites. Local news index databases were also searched for articles in the business press.

All interviews were recorded and, subsequently, fully transcribed. For all stages of the research, the analysis of the case study data was carried out according to 'guidelines' suggested in the literature (e.g., Miles and Huberman 1994; Lindgreen 2001b). Following this, an initial paper was written and sent to each participant for review (the paper was returned by all participants). This 
review process, the use of multiple sources of evidence, and the use of multiple sources of evidence, all helped improve the validity of the data (Eisenhardt 1989; Yin 1994).

In the following discussion we will support our findings with interview quotations from Tesco and/or the meat suppliers, and we will make references to the existing literature (including the business press) and the policies and guidelines that Tesco and the meat suppliers have put down in writing. Doing that, we hope to document that our case has been constructed using a variety of different sources of information, which is one of the requirements when conducting a case study.

\section{Discussion of Findings}

The structure of the traditional UK meat supply chain has been illustrated in Figure 1.

[Take in Figure 1 about here]

Most livestock is purchased from farmers by abattoirs for slaughtering or by processors for processing. They purchase directly from individual farmers, producer groups, or through live-ring auctions. Livestock sales through dealers have declined since World War 2, whilst livestock sales through electronic auctions have increased since 1989 when it was first introduced in the UK. Abattoirs also slaughter a small proportion of livestock on behalf of butchers who carry out the processing and retailing operations themselves. Some meat products are imported and purchased by abattoirs, secondary processors, retailers, or caterers. Having processed the meat, abattoirs sell the products to retailers, butchers, caterers, and secondary processors, or they export the products. 
A part of the meat industry still first passes through wholesalers and distributors (Fearne and Hughes 1998).

Tesco, and other major retailers in the UK, are challenging the structure of the meat supply chain, however. The Tesco Meat Category Director thus recently argued that the structure is too complicated and that it is difficult for retailers to set up effective food safety and animal welfare policies:

We couldn't have designed a more tortuous supply chain if we'd tried ... The job of sourcing the specification of meat that our customers were demanding [is] very difficult indeed [when consumer sensitivity to meat safety and animal welfare was creating a need for transparency and simplicity]... I would be surprised if the various investigations taking place into the lessons learned from foot and mouth do not have something to say about the network of livestock dealerships and auction markets when they reach their conclusions. (Tesco Meat Category Director Steve Murrells, The Grocer 2001: p. 27)

This view of the need for a new approach, and the encouragement of farmers to engage in partnerships with retailers and other parties of the supply chain, is now coming from many influential governmental and non-governmental agencies, too. The view is succinctly expressed and endorsed by the agricultural consultants Promar International (Promar International 2000) who describes the need for an integrated supply chain and for the establishment of 'Producer Partnerships' as a route for survival and as a means of getting closer to the end-consumer.

In a SWOT analysis of UK farming that Tesco carried out (Ling 2001), the company has identified co-operation through vertical and horizontal integration as a major opportunity for addressing consumers' lack of confidence in food safety and animal welfare (Figure 2). For 
example, co-operatives in the UK are small or non-existent while their counterparts in Denmark are very large indeed (e.g., Danisco controls 94 per cent of pig slaughtering in Denmark).

[Take in Figure 2 about here]

Because of the issues highlighted by Murrells, Tesco has sought to simplify the meat supply chain, as illustrated in Figure 3. Livestock are still transported to suppliers (i.e., abattoirs and packing stations) but the roles of the wholesaler and distributor have diminished in importance. That is, Tesco now buys directly from suppliers using a centralised distribution system, and the meat products are first delivered to central warehouses before being distributed to individual retail stores (Fearne and Hughes 1998). Overall, the supply chain is viewed as one supply chain (and not as a number of more independent supply chains as was the case in Figure 1) in which all parties work together in order to deliver the combination of product-quality that the consumers are asking for. This also means that the relationships between Tesco and the meat suppliers become long-term supply relationships, and that the supply chain must allow for transparency, communication, and trust.

[Take in Figure 3 about here]

We will now discuss in detail how the simplified Tesco meat supply chain functions. Although most of the initiatives were first proposed and/or implemented by Tesco, the meat suppliers now run some of the programmes themselves. The suppliers are also required to be more pro-active coming up with ideas for how to make the supply chain 'better'. The discussion will reflect this division of labour. After that, we will examine how it is possible for Tesco to monitor how well 
these initiatives have been implemented, and what the benefits (and risks) are for Tesco and the meat suppliers.

\section{Tesco Initiatives}

Assurance schemes The concept and practice of 'farm assurance' in the UK is generally applied to issues of food safety, animal welfare, and environmental protection. These principles are enshrined in the policies of validating bodies, often specific to particular sectors of food production and supply. A process of independent inspection usually provides assurance. In the red meat sector, for example, 'Farm Assured British Beef and Lamb' was established in 1992 to provide consistently high standards on British livestock farms. It thus existed in advance of the mad cow and the foot-and-mouth crises and proved a significant factor in providing full traceability within the supply chain (Wiltshire 2001). Similar assurance schemes are found with regard to other livestock and meat products such as poultry, pork, and eggs. Consumer awareness of the kind of farm assurance provided by such schemes comes in the form of assurance logos and brand images such as the familiar British Farm Standard 'red tractor' logo, an initiative of the UK National Farmers Union that is adopted on a wide range of British quality assured produce including meats (Wiltshire 2001). Assurance with respect to the Tesco meat supply chain is controlled by Tesco themselves, as well as by independent auditors. Tesco view EU law as a 'baseline' for assurance and, accordingly, for UK law, with added clauses. Tesco standards and 'Codes of Practice' (see shortly) are linked closely and interpret national farm assurance schemes, and cover all aspects of food safety and animal welfare. Tesco additionally strive to provide higher levels of animal welfare and food safety beyond the industry and legal norm. 
Marketing communications In its communications to its various stakeholders Tesco emphasises that it is "committed to providing ... the highest quality fresh meat, fish, eggs and dairy products by ensuring the highest standards of animal welfare and food safety" (Livestock at Tesco 2001). It is exactly because of the crises in the food industry that Tesco has sought to improve its communications strategy:

You try and support the industry and provide information to the industry, and I have regular meetings with farmers and producer clubs, and provide information. (Tesco Agriculture Manager)

Research To reach this objective, Tesco is carrying out in-depth research on how to keep and transport livestock and is sharing the findings with farmers and other suppliers. For example, the retailer funds communication projects and research projects at Bristol University, Harper Adams University College, and at Oxford University Farm, all in the UK. These projects promote specific animal-centred training courses for suppliers, or increase farmer and consumer awareness of best practice in food production.

Animal, feeds, and medicines policies Tesco has also brought together a number of different policies in its 'Codes of Practice' that are compiled from many sources including industry-sourced information, research (e.g., the Tesco Fellowship on Animal Welfare at Bristol University), advice from non-governmental organisations, and consumer feedback (Livestock at Tesco 2001). The policies, which are linked closely with national farm assurance schemes and cover all aspects of food safety and animal welfare (Tesco 2001). 
As part of each policy, Tesco is co-operating and collaborating with a number of different partners. This has been illustrated in Table 2 .

[Take in Table 2 about here]

$\underline{\text { Partnership guidelines }} \quad$ Tesco has put down guidelines for all its meat suppliers to which the suppliers agree:

There is a partnership between us. We cannot do anything without the supplier. Everything is discussed [and] agreed. We negotiate on it [guidelines] heavily because they [the suppliers] are the ones that have to implement it for us. (Tesco Agriculture Manager)

For example, all fresh beef suppliers are required to comply with the 'Code of Practice', as well as legal requirements of husbandry and welfare and the government's 'Code of Recommendation for Cattle Welfare'. Beef suppliers are also required to be members of a recognised assurance scheme such as 'Farm Assured British Beef and Lamb' in England or 'Farm Quality Assurance Scheme' in Northern Ireland (Livestock at Tesco 2001). Strict guidelines are provided on not only housing and feeding facilities, diet, medical treatment, and surgery, but also transportation, traceability of movements, staff involved in the care of animals, as well as inspections of Tesco personnel and of independent inspectors including official veterinary surgeons representing the Meat Hygiene Service (responsible for animal welfare and public health at abattoirs).

$\underline{\text { Tesco Meat Category Manager }}$

The Meat Category Manager is head of the buying team for fresh beef, pork, and lamb. His team of buyers will meet formally with all the suppliers on an annual basis, and less formally on a quarterly basis, to discuss the suppliers' performance. On an 
almost daily basis, Tesco will discuss with an individual supplier issues that include business performance, new product development, market understanding, and technical improvements to reduce cost and wastage.

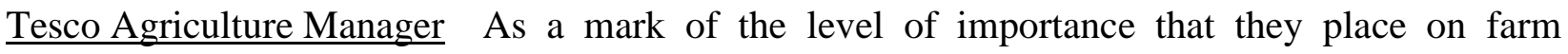
assurance, Tesco have had in post for the past five years an Agriculture Manager who is responsible for animal welfare, food safety, environmental concerns, and farmer and media issues that relate to assurance. This is a unique role in UK retailing. Acting as the Tesco point of contact, the manager will normally meet with the suppliers, both in individual meetings and in collective suppliers' meetings (three to four times a year). The number of individual meetings will depend on the nature of the meetings such as agricultural or processing issues:

I would meet with them all in supplier meetings, which we run about three times a year, and go and visit them at least once a year, and audit them with an auditing company four times a year. (Tesco Agriculture Manager)

As a group of suppliers ... to Tesco, we would meet at least three-to-four times a year. These would be ... meetings where we would talk about codes of practice, [current] issues, future issues, and really having to approve things. But on a one-to-one basis I would say that we meet at least once a month. We would have [telephone or e-mail] communication probably every other day. (Meat supplier 1)

Auditing Together with an auditing company, the manager will carry out an audit four times a year to establish whether or not a supplier performs according to the standards that have been agreed upon. Tesco is currently implementing an initiative that will provide consumers with service information (via telephone and in-store service) about these standards. Each supplier is then evaluated using key performance indicators (see shortly). 


\section{Meat Supplier Initiatives}

Farm assurance schemes $\quad$ Meat suppliers are an integral part of the provision of an integrated supply chain approach to farm assurance. A good example of this is the 'Best Beef Scheme', which aims to provide a 'completely traceable, welfare driven beef chain, from calf to consumer' (Best Beef Scheme 2000). This initiative was brought about as a collaboration of all supply channel members - from calf rearers and livestock farmers to processors, caterers, and Tesco themselves.

Collaborative partnerships 'Partner' suppliers to Tesco commonly collaborate to produce regular newsletters that highlight their integrated approach to livestock and meat supply. One example is even entitled 'Partners in Production: Quality through Partnership with Tesco'. Ideas and practice often originate from the Tesco meat supply base. Such an initiative is the 'Producer's Club' concept:

The 'Producer's Clubs' were all about us moving our interests and supply chain a step further down and onto farm, and that was largely to do with BSE. This was about us trying to assure our consumers with the product integrity all the way down the supply chain. The Competition Commission (an investigation into retailers and their supply practices) was uncomfortable with retailers having producer's clubs because they viewed them as being anti-competitive. So now we encourage our suppliers to manage their own producer's clubs. They are effectively managed for Tesco but not exclusively. (Tesco Meat Category Manager)

'Partner' suppliers of livestock to Tesco, for example, with beef animals, develop on-going partnerships with a core of high quality farmer suppliers, who meet the exacting assurance standards of the Tesco supply chain. It is the processor partner, rather than Tesco, who maintains 
farmer relationships and the operation of the club and, hence, is the primary link in the chain for livestock farmers.

Research Joint research is being carried out between Tesco and the meat suppliers with each party contributing to the costs of such research:

We would do collaborative research in terms of livestock. The Tesco supply base would fund [research]. For example, we have just done some research into farrowing systems with pigs with the whole supply base. Tesco would put in half of the money, and the six suppliers would fund the rest. The 'Best Beef Scheme' would be an example of where we would link up with various beef suppliers. (Tesco Agriculture Manager)

Marketing communications Tesco and the meat suppliers have also implemented joint marketing communications to ensure that the consumers will be convinced that British meat is safe. This has especially been important for the suppliers who often are not as skilled in marketing communications as Tesco:

We did everything possible to get consumer confidence back. We said, "look, this is a brandnew plant. Anything we kill here has not had contact with anything that is over 30 months [old]." We don't communicate directly with the consumer because if we tried to do that we could give out the wrong message quite easily because we are not professionals at dealing with this. ... [What] we are doing ... is [dealing] with [it] on a partnership basis. (Meat supplier 1)

\section{Monitoring of Initiatives}

Each supplier is evaluated using a number of different key performance indicators: for the financial strength of the business, the ability of the business to innovate and to add value, the business' preparedness to invest, as well as the capabilities of the business' employees and service levels. The evaluation is done independently by Tesco and the supplier who will meet 
afterwards and agree upon the final evaluation. It is felt that the evaluation process has improved the meat suppliers' standards and results:

It [the key performance indicator process] is a good thing. It has certainly focused suppliers on audit results and standards. (Tesco Agriculture Manager)

Some examples of typical key performance indicator evaluations are shown in Appendix 2. Each key performance is evaluated and the score is indicated on a scale from 1 to 10 . At the same time, a 'traffic-light' colour scheme is being used (where red-highlighted scores indicate possible serious problems to be addressed; amber indicates issues to be monitored; and green indicates a good score and, therefore, good practice). This approach makes it much easier to obtain and act upon immediate feedback. In general, suppliers, who are expected to improve in areas where they are weak, are happy with being evaluated, as evidenced in the following text units:

I think that it [the key performance indicator process] enables you to distinguish between the good suppliers and the not so good suppliers. I am pleased that Tesco are using [this system] to reward those suppliers that are performing well and to take business off those that are not. I am all for it. (Meat supplier 2)

It is quite [a] good exercise. ... It [the key performance indicator process] gives you that ability to understand what they [Tesco] think of you, which is quite useful. You can take it back to your business and you can tailor the work within your business and your prioritising of development[s] to make sure that your are developing areas that you are weak in. (Meat supplier 4)

The remaining findings from the research will now be discussed under the following headings:

- relationships between Tesco and meat suppliers and

- benefits to relationships forming 


\section{Relationships between Tesco and Meat Suppliers}

Multiple points of contact There is no longer a single point of contact between Tesco and meat suppliers. Instead, relationships take place between several different functions, as evidenced in the following text unit:

There has been a change in the last five or six years to matrix management where there is an NPD [new product development] manager linked into [Tesco]. ... We have a dedicated technical manager who links up with their technical [function], as well as someone who looks after their agricultural and welfare issues. As a supplier, you might have felt that [when there was only a dyadic buyer-seller relationship rather than a matrix relationship] you had more of a control where there was a 'funnel' contact to a couple of people. But, certainly, business is [now] a lot more complex that it [used to be]. (Meat supplier 2)

Figure 4 illustrates how organisations are now working together between different functions. The dotted line separates the meat supplier from Tesco although it has become increasingly difficult to distinguish between the business entities. For example, some of the meat suppliers will have a number of their employees placed at Tesco where they will work together with their Tesco counterparts.

[Take in Figure 4 about here]

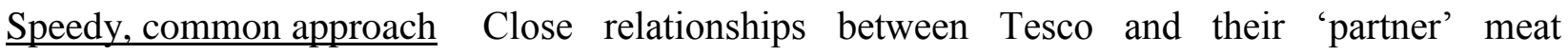
suppliers allow a common supply chain approach to external sector problems and influences (such as consumer concerns with regard to food scares). Regular and open channels of communication in the supply chain allow for quicker problem resolution and joint decision making. The relationships also allow to bring together people with different expertise. 


\section{Benefits to Relationship Forming}

Cost, quality, and safety control An obvious benefit to the closer co-operation between Tesco and the suppliers is cost savings, which can be passed on to the consumer. The decreased number in suppliers, which partly explains these savings, also lead to an easier and more effective control of the remaining meat suppliers who have higher quality and safety control than the smaller suppliers outside the Tesco supply network:

What happens when you deal with a smaller supply base is that it reduces your costs so first of all it makes you more cost effective at consumer level. That was a huge benefit and those that can do it for a reasonable level [return] will survive. It is much easier to audit and keep control with a smaller amount of suppliers as well, and that increases food safety. ... In small abattoirs they do not have the same [quality and safety] controls in place because they do not have the volume to keep costs down. (Meat supplier 1)

Joint systems and responses There are provisional indications that joint systems and responses are in place, established between supply chain members, in order to anticipate and head off future crises:

We all want to sell more Tesco meat. ... You could argue that you could trade [transactionally], but you have not built up a relationship [that way]. All of our suppliers would want to see us [Tesco] successful. You have built up a relationship where their success hinges on ours, and vice versa. Sometimes you have bad times with a supplier, but they [bad times] are far outweighed [by good times]. (Tesco Agriculture Manager)

The confidence to invest in our business is based on the fact that we do not chop and change suppliers. (Tesco Meat Category Manager)

We would like to think that the level of service that we offer our customers was perhaps better than some other people [other retailers]. In times when there are shortages in the market this is when loyalty comes to the fore so in the same way that we look for loyalty in our customers, through servicing them with what they are looking for, we are able to do that because we are loyal over time to our suppliers. Whereas some other retailers or market- 
facing outlets were suffering 'out of stocks' we like to think that we had a really good level of availability. When the chips are down we will serve product and other people [other retailers] will not, and that is testament to a good relationship [with suppliers]. (Tesco Meat Category Manager)

Consumer value The suppliers argued that the benefits of Tesco having a select supplier base has meant that they have had to respond more professionally to the challenges posed by Tesco. The suppliers who succeed in doing that were selected as suppliers and saw their volume of business increasing. One of the keys driving the selection process was delivering customer value:

I would say that the relationship [with Tesco] has made [our] business more professional. It is really a 'wake-up call' as much as anything. Everything that Tesco does is purely customer driven. ... All they have really done is put that into 'supplier speak'. You know, "this is what we really need [from the suppliers]. How can you do it?" ... We have increased our volume because we have been more professional. (Meat supplier 1)

Ultimately what they [Tesco] are going to try ... is [to] increase your volume via more sales, and more sales are profitable. But we are not looking for huge margins, and you will never get huge margins, and people who are after huge margins are actually shut [off].. So what we are looking to do is [to] increase volume. Everybody wants to earn more money, and if you are doing things right and you are [a] good partner then you will get more business and, ultimately, you will be more profitable. (Meat supplier 1)

Preferred meat supplier It also means that if a supplier first has been selected then it is much more likely that Tesco will continue to do business with this supplier when they moved into new territory:

If you prove to be a good supplier then you can effectively supply meat to Tesco anywhere in the world, and that is really where the real partnership comes in. They [Tesco] are taking us with them. They could say, "OK, we will get in another supplier because they can do it cheaper", but it doesn't work like that. What they will say is, "they [i.e., the meat supplier] have a proven track record and they are as safe as you can get, and we need to take these guys with us". (Meat supplier 1) 
The decision of supplying Tesco has been made deliberately by the meat suppliers even though it in some cases means that a particular meat supplier no longer can supply to other similar largescale competitor retailers:

Over the years, we have had to make decisions ... with regard to existing relationships with other companies. The biggest one was four years ago when we made the decision to stop trading with J. Sainsbury and decided to go wholeheartedly into developing our business and relationship with Tesco. (Meat supplier 4)

New product development Delivering value to the customers also means developing new products as an effective means of being superior to competitors. Only if a meat supplier is better than competitors is there an incentive for a retailer to change to his products, as evidenced in the following story:

I always remember going to Japan ... It was along flight and I had rehearsed ... "we are as good as the Danes. Our product is like the Danes' [product]. But at the end of one meeting, one guy said, 'so you are as good as the Danes, but unless you are better why should I change [supplier]?' It was a long flight back and I came to understand that we have got to be better for this guy to change [supplier]. (Meat supplier 2)

Often, Tesco has a better perception of what it is that the consumers want:

I think that what the retailers, particularly Tesco, are [good at driving] are things that they see as priorities ... They can see more from the consumers' perspective whereas we might see things as industry issues. That is the value [of working together with Tesco]. ... By being asked to develop [new] products, by being asked to meet very high service levels, by looking at the value chain and taking costs out. (Meat supplier 2)

This would, however, depend on whether the meat supplier produces under his own brand or under the Tesco brand: in the former case the supplier will be more proactive in seeking to understand the consumers and to make sure that the consumers are aware of his existence: 
We are ... proactive when it comes to consumers because we are an own brand supplier. ... What we are doing is [to] support [the] brand and [give] confidence to [the] consumers. In areas like free-range, for example, we would be ... putting together information leaflets. For organic [areas], we would [be] putting together leaflets explaining why it is different and providing information for websites, which go directly to the consumer[s]... We are pushing a bit further than [what] Tesco would like us to do in some respects. What we wanted to do was [to] have links from their website to our website so they [the consumers] could look at free range farms or organic farms and get some information. (Meat supplier 4)

Overall, both parties believe that the supply chain is better able to respond to consumers' concerns about food safe and animal welfare:

We see ourselves as stepping up our game all of the time. We like to think that we have all of the steps in place necessary to respond to something like a food scare: a BSE scare, a hygiene scare. Our responsibility is that we have everything covered. (Meat supplier 1)

Extra supplies Another benefit of being a large customer is that in a crisis the meat suppliers will be prepared to supply extra quantities of meat products if necessary. This happened during foot-and-mouth disease when there was a huge demand for poultry products, and Tesco was supplied with extra quantities of such products. After the crisis, the meat supplier was awarded increased business as a 'token':

During foot-and-mouth, we came to their [Tesco's] rescue and [were] able to make sure that they had got supply through that period. There was enormous demand [for chicken because of uncertainty in other meat sectors]. The other example was during the fuel crisis [in 2000] where we had contingency plans in place so that we were able to ensure that none of their supply was hindered at all. I think that was recognised with the award of more business as a consequence. (Meat supplier 4)

\section{Managerial Implications}

Preferred supplier base As explained, developments in the marketing environment has forced Tesco to change their policy toward their suppliers. The policy was first changed when 
Tesco implemented a centrally-packed meat scheme some ten years ago: instead of dealing with a vast number of raw material suppliers Tesco would invest in working together with a few suppliers in retail packing facilities. Those suppliers were selected according to criteria still applicable:

[Those suppliers some ten years ago] would have been selected on the criteria that we use today: product quality, service, cost, leadership, and effectively the will to innovate and take a leap of faith for Tesco. (Tesco Meat Category Manager)

Difficult to manage a matrix organisation As discussed in the article, relationships between Tesco and its meat suppliers take place between several different functions, some of which have been described. Although there are many advantages of replacing the simple dyadic buyer-seller relationship with a relationship that is supported by contacts between matrix organisations some managers argued that it becomes more difficult to control what happens. These managers found that whether or not the matrix organisation with many relationships would work depends on how successful the individual meat supplier or retailer is:

There is a danger ... [with matrix management] that you lose the common thrust, the common thread, and the more people you have got, [the more] they can go off in slightly different directions. But I suppose that [controlling the success of the matrix] is down to the supplier and customer operating and managing their own individual teams. (Meat supplier 1)

The managerial implications are clear: although increasingly business entities are working together at several different functions it is still necessary for the individual organisation to implement some kind of control. Most importantly, there must be systems in place that communicate to all members what is happening. This was sometimes found to be wanting at this time: 
The biggest fundamental issue I would have is with communication at the account [of Tesco]. The [lack of] communication that goes on within Tesco, and that is the biggest failing, I think. The rest of the team never know what is going on. ... I think that there are certain departments in Tesco that have got to do a bit of work on communications. That is the one thing to watch: that everyone knows what is happening and agreeing. (Meat supplier 4)

\section{Conclusions, Limitations, And Future Research}

\section{Conclusions}

As a result of our investigation and case analysis, we conclude that an integrated and relationship-based, supply-chain approach to business-to-business dealings can provide real benefits to partners and enable them in turn to deliver quality and performance improvements to end consumers. Additionally, Tesco and their supply chain seek to jointly tackle specific consumer issues regarding animal welfare and food safety. With respect to the UK meat industry, the Tesco approach to supply chain relationships has been timely, namely it has been developed at the time of profound industry crisis. This article highlights issues and some new aspects of supply chain and relationship management, for example in the development of the key performance indicator process and in the shared an joint approach to problem solving.

\section{Limitations}

The research included interviews with organisations and people in current buyer-seller partnerships, as well as archival data at Tesco and local news index databases. The researchers 
did not approach any consumers, and this constitutes a weakness of the research design. Future research should probe for consumers' views on Tesco's communications strategy (see shortly).

\section{Future Research}

The research found that communications to various stakeholders is an important part of a business's communications strategy. But research carried out by Tesco suggests that some consumers do not trust the information that they receive:

Research that we did suggested that a proportion of consumers did not trust the fact that it [foot-and-mouth disease was not going to endanger human health so there were some particular concerns at the margin. The evidence would suggest that the core meat purchaser was not affected and continued to buy meat. But the research will also show that there is an increasing number of people either concerned about food safety, or about the meat supply chain itself in terms of the common sense of the supply chain, [animal] welfare, farmer welfare, and that sort of thing. (Tesco Meat Category Manager)

It therefore becomes necessary for businesses - and other organisations such as governmental bodies - to find out how it is possible to put forward information that is right, and that consumers will trust.

Transparent, tangible communications Research could examine what went wrong during a crisis such like that of mad cow disease: in this particular case, it has been suggested, that incompetence and, indeed, secrecy in the British Ministry of Agriculture, Fisheries, and Food have surrounded mad cow disease, with examples of British officials refusing to help outside researchers or hiding information (The Economist 1998a, 1998b). At this point, Tesco has found that whatever it gives to the consumers has to be transparent, as well as tangible. 
large number of suppliers that would compete on lower prices that could be passed on to the consumers or having a small number of suppliers who could be 'controlled' more effectively by

Tesco. Some consumers also would like to be supplied from local abattoirs:

Dealing with a smaller number of abattoirs is a really good thing for the integrity of the food chain. It means that you are far better able to control the service that you offer customers, the quality of the product, the integrity of the product, etc., which is fundamental in terms of food safety and the welfare of the animals. But, of course, people want to be supplied by local abattoirs. I think that it is important that we continue to try to improve the animal welfare in the chain and that, ultimately, food safety has got to be king. You cannot ensure food safety in an organisation the size of ours [Tesco] unless you can control the supply chain to some degree or, at least, monitor the supply chain, ensure the traceability, do the checks, do the audits, all that sort of things. It is very difficult to do it if you have a completely diversified supply chain. (Tesco Meat Category Manager)

Co-operation and competition with the same company

Yet a third avenue would be to look into how meat suppliers are dealing with the fact that they are sitting in category teams at Tesco's place. This way of doing business means that a supplier will have to discuss aspects of them doing business that they would never have done earlier:

What we are not frightened to do is [to] enlist the help of other suppliers in that relationship. At the moment, we have a three-way category meeting going on, with [a named competitor supplier] and Tesco. So it is not being afraid about your competition; it is understanding your competition's business: what their aspirations are, what their share is, and then tailoring [your operations toward] it. (Meat supplier 4)

\section{References}

Anderson, J. C. and Narus, J. A. (1990), “A model of distributor firm and manufacturing firm working partnership", Journal of Marketing, Vol. 54, No. 1, pp. 42-58. 
Best Beef Scheme (2000). "Increasing the value of the beef chain from the calf to the counter: a quality scheme through partnership", joint agency promotional leaflet.

Competition Commission (2000), Supermarkets: A report on the supply of groceries from multiple stores in the UK, Cmnd. 4842 (Summary), The Competition Commission/The Stationery Office, London.

CorporateWatch(2001),“TescoStoresPlc[on-line]”, http://www.corporatewatch.org.uk/profiles/food_supermarkets/tesco/ [accessed 17 December $2001]$.

Daily Telegraph (2001), "Farm fury at millionaires 'leak'”, Daily Telegraph, 6 August, p. 4.

Department for Environment Food and Rural Affairs (2001), "Statistics on foot and mouth, foot and mouth disease", http://www.defra.gov.uk/footandmouth/cases/statistics [accessed 15 November 2001].

Department of Trade and Industry (2001), "Hewitt backs good behaviour code for supermarkets and suppliers", Department of Trade and Industry, press release, P/2001/606, 31 October 2001.

Eisenhardt, K. M. (1989), "Building theories from case study research" Academy of Management Review, 14(4): 532-550.

Farmers Weekly Interactive (2001), "Supermarkets to 'abide by code"”, Farmers Weekly Interactive, http://www.fwi.co.uk/live/news/fwi_news [accessed 18 December 2001].

Fearne, A. and Hughes, D. (1998) Building effective partnerships in the meat supply chain: lessons from the UK. Food Industry Management, Wye College Press, Kent.

Fontenot, R. J. and Wilson, E. J. (1997), "Relational exchange: a review of selected models for a prediction matrix of relationship activities”, Journal of Business Research, Vol. 39, No. 1, pp. 5-12. 
Freedom Food Survey (2001), Executive Summary Report, The Gallup Organisation, Kingston upon-Thames, Surrey.

Goddard, S. (1999), “Illnesses spur Coke recall”, Business Insurance, Vol. 33, No. 25, pp. 25-27. Hingley, M. (2000), Business-to-Business Relationships: Case Studies in Relationship Marketing from the UK Fresh Produce Industry, Cranfield University, MPhil thesis.

Hingley, M. K. (2002), “The value of relationships for customers and suppliers: experience from UK fresh produce industry SME and multiple retailer buyers", International Journal of Logistics Management, accepted for publication in Vol. 12, No. 2.

Hughes, D. (1994), Breaking with Tradition: Building Partnerships \& Alliances in the European Food Industry, Wye College Press, Wye.

Jolly, D. E., Schultz, H.G., Diaz-Knauf, K. V. and Johal, J. (1989), “Organic foods: consumer attitudes and use", Food Technology, Vol. 43, No. 11, pp. 60-66.

Licking, E. and Carey, J. (1999), "How to head off the next tainted-food disaster", Business Week, 1 March, p. 34.

Lindgreen, A. (2001a), "In search of relationship quality, customer retention and shareholder value: findings from an exploratory, qualitative multiple case study", The Journal on Chain and Network Science, Vol. 1, No. 1, pp. 49-63.

Lindgreen, A. (2001b), “A framework for studying relationship marketing," Qualitative Market Research: An International Journal, 4(2): 75-84.

Ling, C. (2001), "The Tesco meat supply chain", Unpublished presentation to Harper Adams University College, Newport, October.

Livestock at Tesco (2001), Published by Tesco Stores Ltd, Cheshunt.

Miles, B. and Huberman, A. M. (1994), Qualitative Data Analysis: An expanded sourcebook, 2nd edition, Sage Publications, Thousand Oaks, California. 
Promar International (2000), "Foot and mouth disease: the catalyst for change in food and Farming”, Promar International, Crewe, Cheshire, UK, September.

Schaffner, D. J., Schroder, W. R. and Earle, M. D. (1998), Food Marketing: An International Perspective, McGraw-Hill, Boston, Massachusetts.

Sharp, J. C. M. and Reilly, W. J. (1994), "Recent trends in foodborne infections in Europe and North America", British Food Journal, Vol. 96, No. 7, pp. 25-34.

Tansey, G. and Worsley, T. (1995), The Food System: A guide, Earthscan Publications, London Tesco (2001), Interim Report and Accounts, August 2001, Tesco Plc, Cheshunt, Herts, UK. The Economist (1998a), "The science of BSE: bungled”, The Economist, 14 March, pp. 21-23. The Economist (1998b), “The science of BSE: birth of a disaster”, The Economist, 14 March, p. 22.

The Grocer (2001), ’Tortuous meat supply chain blasted by Tesco”, 6 October, p. 27. Wandel, M. (1994), 'Understanding consumer concern about food-related health risks", British Food Journal, Vol. 96, No. 7, pp. 35-40.

Wilson, E. J. and Vlosky, R. P. (1997), "Partnering relationship activities: building theory from case study research", Journal of Business Research, Vol. 39, No. 1, pp. 59-70.

Wiltshire (2001) “Assurance/traceability: consumers' say they want it, so why am I the one paying for it?" AgriVision Conference: Focusing on Farming's Future, Royal Agricultural Society of England (RASE), National Agricultural Centre, Stoneleigh Park, Warwickshire, 5-6

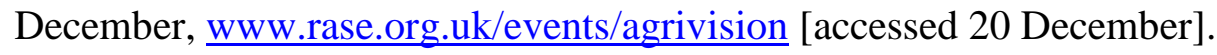

Yin, R. K. (1994), Case Study Research: Design and Methods, 2nd ed., Sage Publications, Thousand Oaks, California.

Zimmerman, L., Kendall, P., Stone, M. and Hoban, T. (1994), "Consumer knowledge and concern about biotechnology and food safety”, Food Technology, Vol. 48, No. 11, pp. 71-77. 


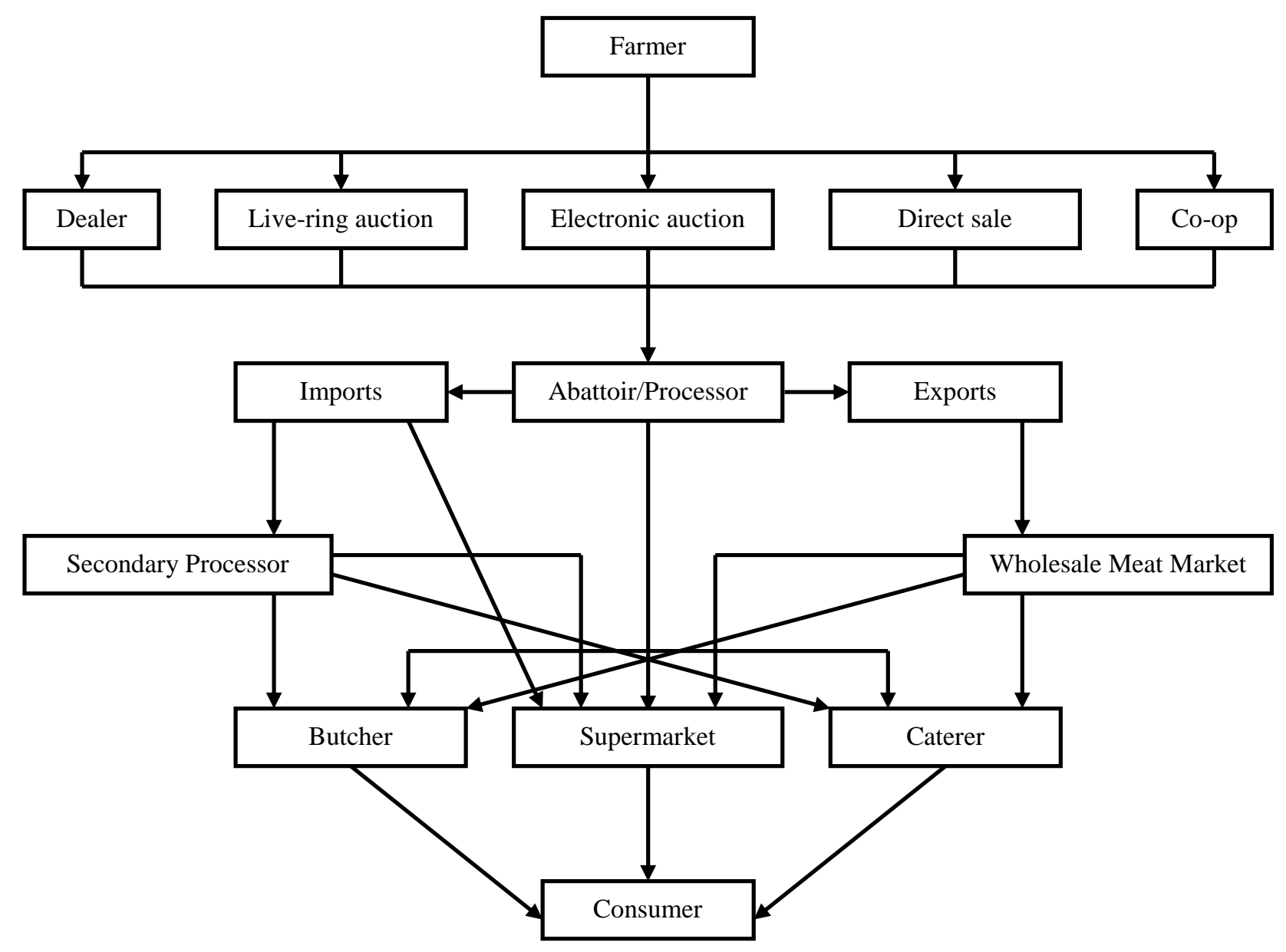

Figure 1. The UK meat supply chain

Source: Fearne and Hughes (1998: p. 6) 


\section{Strengths}

- Home market

- Close to consumers

- Fertile land

- Good technical skills

- World-class breeding

\section{Weaknesses}

- Tight regulation

- Much political influence

- High land costs

- High market awareness

- Lack of co-operation

- Lack of investment

- Foot-and-mouth disease

\section{Threats}

- Variations in currency

- Cheaper overseas land and labour

- Export of technical skills

- Various diseases

Figure 2. SWOT analysis of UK farming

Source: Ling (2001) 


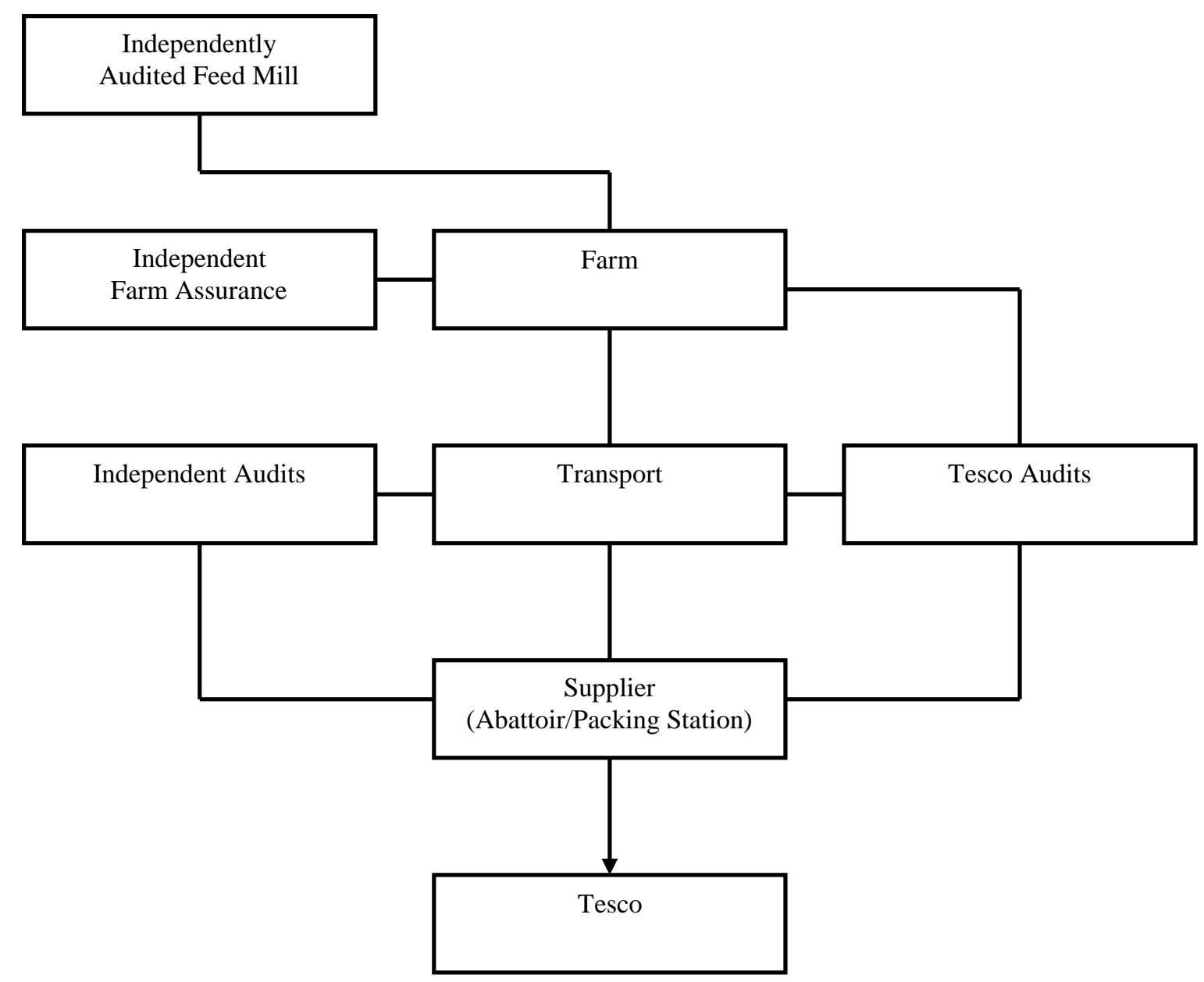

Figure 3. The Tesco meat supply chain

Source: Livestock at Tesco (2001: p. 4) 


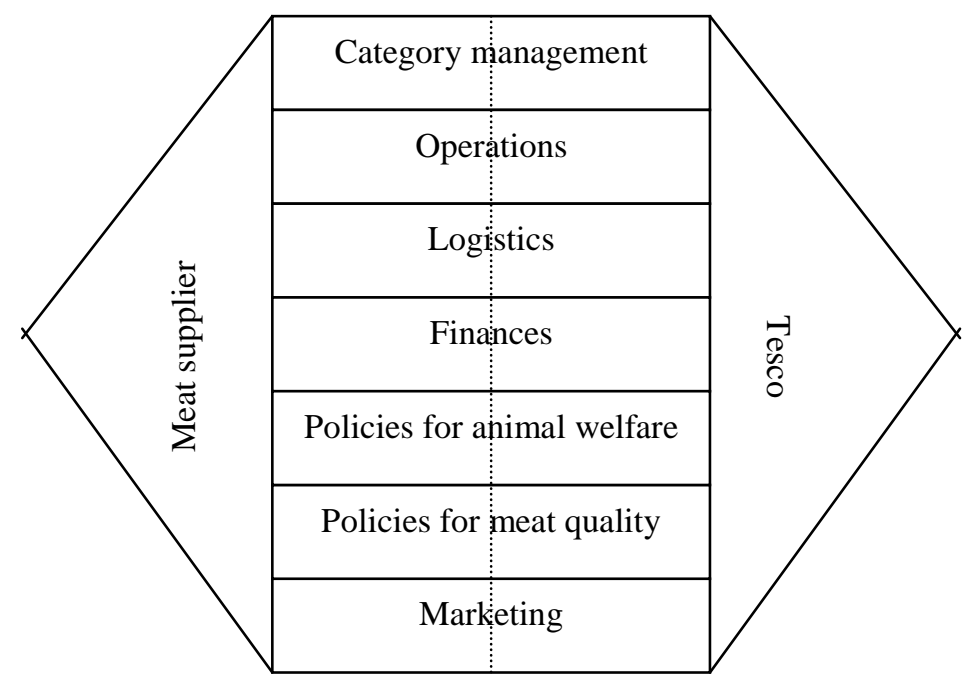

Figure 4. Relationships between Tesco and a typical meat supplier 
Table 1. Interview organisations, respondents, and the roles of the respondents

\begin{tabular}{|c|c|c|}
\hline Organisation & Respondent & Role \\
\hline Tesco Manager 1 & Meat Category Manager & Head of the category buying team for red meat \\
\hline Tesco Manager 2 & Agriculture Manager & $\begin{array}{l}\text { Responsible for animal welfare, food safety, and } \\
\text { environmental concerns in the Tesco meat supply } \\
\text { chain }\end{array}$ \\
\hline Meat supplier 1 & Managing Director & $\begin{array}{l}\text { Overall senior responsibility of livestock and meat to } \\
\text { Tesco }\end{array}$ \\
\hline Meat supplier 2 & Chief Executive Officer & $\begin{array}{l}\text { Overall senior responsibility of livestock and meat to } \\
\text { Tesco }\end{array}$ \\
\hline Meat supplier $3^{\mathrm{a}}$ & Managing Director & $\begin{array}{l}\text { Overall senior responsibility of livestock and meat to } \\
\text { Tesco }\end{array}$ \\
\hline Meat supplier $3^{\mathrm{b}}$ & Marketing Director & $\begin{array}{l}\text { Responsible for sales and marketing activity } \\
\text { including new product development and public } \\
\text { relations }\end{array}$ \\
\hline Meat supplier $4^{\mathrm{a}}$ & Sales and Marketing Director & Responsible for all meat sales activity with Tesco \\
\hline Meat supplier $4^{\mathrm{b}}$ & Group Marketing and PR Manager & $\begin{array}{l}\text { Responsible for group brands marketing and public } \\
\text { relations }\end{array}$ \\
\hline
\end{tabular}

Note: The names of the meat suppliers have been withheld for reasons of confidentiality. Meat suppliers interviewed are principal 'partner' suppliers in the major categories of beef, lamb, poultry, and pig meat. a and b means that for this particular meat supplier two people within the organisation were interviewed. 
Table 2. Examples of partners with whom Tesco co-operates and collaborates

\begin{tabular}{|c|c|}
\hline Policy & Examples of partners \\
\hline 'Tesco Animal Welfare Policy’ & $\begin{array}{l}\text { Veterinary surgeons and various farm assurance schemes, to ensure } \\
\text { that the policy for surgical procedures entails the use of the least } \\
\text { painful procedures (as defined by research and/or pain-relieving } \\
\text { techniques). } \\
\text { - Assured British Meats' Transport Scheme, a scheme that hauliers } \\
\text { must be approved under. }\end{array}$ \\
\hline \multirow[t]{3}{*}{ 'Tesco Animal Feeds Policy’ } & $\begin{array}{l}\text { - Feed mills, to ensure that they are operate to United Kingdom } \\
\text { Agricultural Supply Trade Association's Feed Assurance Scheme } \\
\text { standards (or equivalent). }\end{array}$ \\
\hline & $\begin{array}{l}\text { - Assured Combinable Crops Scheme, a scheme that Tesco encourages } \\
\text { farmers to be members of. }\end{array}$ \\
\hline & $\begin{array}{l}\text { Veterinary surgeons, the food industry and representative bodies, to } \\
\text { ensure that the use of antimicrobials is minimised. }\end{array}$ \\
\hline \multirow[t]{3}{*}{ 'Tesco Animal Medicines Policy' } & $\begin{array}{l}\text { Veterinary surgeons and various farm assurance schemes, to define } \\
\text { regular treatment regimes and the process for dealing with sick and } \\
\text { injured animals. }\end{array}$ \\
\hline & $\begin{array}{l}\text { - The food industry, to draw up guidelines on how to use medicines } \\
\text { responsibly in agriculture. }\end{array}$ \\
\hline & $\begin{array}{l}\text { Other representative bodies, to draw up guidelines on how to use } \\
\text { medicines responsibly in agriculture. }\end{array}$ \\
\hline 'Tesco Pathogen Reduction Policy’ & $\begin{array}{l}\text { - Veterinary surgeons, the food industry and representative bodies, to } \\
\text { agree on guidelines for responsible use of medicines in agriculture }\end{array}$ \\
\hline
\end{tabular}




\section{APPENDIX 1}

\section{The Interview Schedule}

Tesco personnel (A): The following areas for discussion concerning your relationships with meat sector suppliers in general and with specific reference to the three named suppliers.

Supplier personnel (B): The following areas for discussion concerning your relationships with retailers in general and with specific reference to Tesco.

1. Outline the history and development of your relationship(s).

2. Describe the nature of communications and meetings that you have, with whom and when.

3. What is being discussed in such communications and meetings?

4. What kind of documentation exists between you? What does this documentation detail?

5. If appropriate, how was this developed?

6. Describe the nature of any form of relationship performance evaluation.

7. Describe the nature of any joint collaborative activity between supplier(s) and retailer (that is, Tesco) (for example: joint research, joint marketing efforts, feedback of shared market information, planning arrangements and product, systems and market innovation).

8. How did your organisation respond to specific recent meat industry crises / consumer issues (such as animal disease and animal welfare)?

9. In what ways did this involve your (supplier / retailer) relationship(s)?

10. What steps have you taken as an organisation to establish / re-establish consumer confidence in your sector of the meat and livestock industry?

11. In what ways does this involve your (supplier / retailer) relationship(s)?

12. What role has 'partnership' status played in the development of the industry and the establishment / re-establishment of consumer confidence?

13. What role has 'partnership' arrangements in the livestock / meat industry played in the management of governmental and media relations? 


\section{APPENDIX 2}

\begin{tabular}{|c|c|c|c|c|c|c|c|c|}
\hline & BEEF & LAMB & PORK & TURKEY & CHICKEN & EGGS & FISH & MILK \\
\hline ANIMAL WELFARE & 4,6 & 3,7 & & 2,0 & 5,6 & 1,9 & & 3,7 \\
\hline TRACEABILITY & 4,0 & 3,2 & & 2,4 & 3,7 & 3,3 & & 4,2 \\
\hline PROCEDURES & 1,9 & 2,3 & 5,0 & 5,8 & 4,8 & 6,1 & & 5,0 \\
\hline FOOD SAFETY & 2,5 & 2,8 & 1,5 & 1,8 & 2,6 & 4,8 & & 3,7 \\
\hline ANIMAL MEDICINES & 3,6 & 3,2 & 2,7 & 3,8 & 3,3 & 2,8 & & 4,7 \\
\hline
\end{tabular}

Figure a. An actual evaluation of one supplier across a range of meat products

Note: The darkness of the cells indicate the colour scheme that is being used.

\begin{tabular}{|c|c|c|c|c|c|}
\hline Supplier comparison & & & & & \\
\hline Product $A$ & & & & & \\
\hline & Company 1 & Company 2 & Company 3 & Company 4 & Company 5 \\
\hline$\%$ of Tesco Supply & 50 & 16 & 17 & 7 & 10 \\
\hline ANIMAL WELFARE & 3,7 & 1,0 & 5,0 & 3,7 & 5,7 \\
\hline TRACEABILITY & 2,7 & 2,7 & 4,7 & 2,0 & 4,7 \\
\hline PROCEDURES & 2,0 & 2,0 & 1,0 & 2,0 & 7,0 \\
\hline FOOD SAFETY & 2,3 & 2,3 & 3,7 & 1,7 & 5,7 \\
\hline ANIMAL HEALTH & 3,0 & 3,0 & 3,0 & 2,3 & 5,0 \\
\hline TOTAL & 2,7 & 2,2 & 3,5 & 2,3 & 5,6 \\
\hline
\end{tabular}

\section{Figure b. An actual comparison of different meat suppliers on a range of issues}

Note: The darkness of the cells indicate the colour scheme that is being used. 


\section{Autobiographical Notes}

Adam Lindgreen: $\quad$ After graduating in Chemistry, Engineering and Physics, Adam Lindgreen finished an MSc at the Technical University of Denmark; an MBA at the University of Leicester in England; and a One Year Postgraduate Programme at the Hebrew University of Jerusalem in Israel, after which he worked as a consultant for Andersen Consulting. He then completed a PhD at Cranfield University in England - with 18 months as a Visiting Research Fellow at the University of Auckland in New Zealand. He is now with the Technical University of Eindhoven in the Netherlands, as well as a Visiting Professor with Auckland University of Technology in New Zealand and a Visiting Reader with Harper Adams University College in England. Dr Adam Lindgreen has carried out consulting work for a number of organisations, in Denmark and abroad. He has published in several international journals, and received three best paper awards at international marketing conferences.

Contact details: $\quad$ Adam Lindgreen, Avenue du Centre Sportif 45, Bte 8, 1300 Wavre, Belgium. Email Adam_Lindgreen@ hotmail.com. Telephone + 32 - 10222743.

Martin Hingley: $\quad$ Martin Hingley is senior lecturer in Marketing at Harper Adams University College, in Shropshire, the United Kingdom. His primary interests of teaching and research are in the applied areas of agricultural and food industry marketing and supply chain management. Martin Hingley holds a first degree from the University of Newcastle upon Tyne and a higher degree from Cranfield University. He has wide ranging business experience in the agricultural and food industries and spent some time in provision of market and business analysis and industry based training with the Institute of Grocery Distribution (IGD). Martin Hingley is currently the Tesco Teaching Fellow at Harper Adams. 
Contact details: Martin Hingley, School of Management, Harper Adams University College, Newport, Shropshire, TF10 8NB, United Kingdom. Email mhingley@harper-adams.ac.uk. Telephone + 44 - (0) 1952820 280. Fax + 44 - (0) 1952814783. 